\section{Ciliary neurotrophic factor prevents degeneration of motor neurons in mouse mutant progressive motor neuronopathy}

\author{
M. Sendtner*, H. Schmalbruch $\dagger$, K. A. Stöckli*, \\ P. Carroll*, G. W. Kreutzberg $\ddagger$ \& H. Thoenen*
}

Departments of * Neurochemistry and $\ddagger$ Neuromorphology, Max-Planck-Institute for Psychiatry, D-8033 Martinsried, Germany †Institute of Neurophysiology, Panum Institute, University of Copenhagen, DK-2200 Copenhagen, Denmark

CILIARY neurotrophic factor (CNTF) supports the survival of embryonic motor neurons in vitro ${ }^{1,2}$ and in vivo ${ }^{3}$, and prevents lesion-mediated degeneration of rat motor neurons during early post-natal stages ${ }^{4}$. Here we report that CNTF greatly reduces all the functional and morphological changes in $\mathrm{pmn} / \mathrm{pmn}$ mice ${ }^{5}$, an autosomal recessive mutant leading to progressive caudo-cranial motor neuron degeneration. The first manifestations of progressive motor neuronopathy in homozygous pmn/pmn mice become apparent in the hind limbs at the end of the third post-natal week, and all the mice die up to 6 or 7 weeks after birth from respiratory paralysis. Treatment with CNTF prolongs survival and greatly improves motor function of these mice. Moreover, morphological manifestations, such as loss of motor axons in the phrenic nerve and degeneration of facial motor neurons, were greatly reduced by CNTF, although the treatment did not start until the first symptoms of the disease had already become apparent and substantial degenerative changes were already present. The protective and restorative effects of CNTF in this mouse mutant give new perspectives for the treatment of human degenerative motor neuron diseases with CNTF.

We have evaluated the effects of CNTF in the $p m n / p m n$ mouse, which is an animal model for human spinal motor neuron disease $^{5}$. In contrast to two other mouse mutants, wobbler ${ }^{6-8}$ and $m n d^{9,10}$, the manifestations of motor neuron degeneration in $p m n / p m n$ mice appear earlier and progress more rapidly. In 4-week-old pmn/ pmn mice, the number of axons of the phrenic nerve is already highly reduced, indicating that at this time the

TABLE 1 Effect of CNTF treatment on the number of facial motor neurons and phrenic nerve axons in $p m n / p m n$ mice

$\begin{array}{ccc} & \begin{array}{c}\text { Number of } \\ \text { facial } \\ \text { motor neurons } \\ 1,881 \pm 199^{*}\end{array} & \begin{array}{c}\text { Number of } \\ \text { phrenic } \\ \text { nerve axons }\end{array} \\ \begin{array}{c}(n=6) \\ 87 \pm 4^{*}\end{array} & (n=7) \\ (40-50 \text { days old }) & 2,679 \pm 108^{*} & 144 \pm 22^{*} \\ (n=7) & (n=7) \\ \text { CNTF-treated } p m n \text { mice } & 3,108 \pm 153 & \text { ND } \\ (40-48 \text { days old }) & (n=5) & \\ \text { Healthy control mice } & & \\ \text { (littermates) } & & \end{array}$

The brain stem of mice perfused with $4 \%$ formaldehyde was embedded in paraffin, serial sections $7-\mu \mathrm{m}$ thick were stained with cresyl violet, and the nucleoli of facial motor neurons were counted in every fifth section on both sides as previously described ${ }^{4}$. Counts were not corrected for split nucleoli ${ }^{4,15}$. The mean of the counts on both sides was used for each animal. Phrenic nerves were prepared after perfusion of the animals with $4 \%$ formalin. Nerves were postfixed in $4 \%$ formalin, dehydrated, then $5-\mu \mathrm{m}$ transverse sections made and stained according to ref. 16. Myelinated axons were counted from photographs taken from nerve sections under the light microscope. Data shown are means \pm s.e.m. for each group. ND, not determined

* Statistical significance was tested by Student's $t$-test, $P<0.0005$. disease has already reached an advanced stage. The motor neurons of $\mathrm{pmn} / \mathrm{pmn}$ mice first undergo a reduction in cell size, then chromatolysis and finally cell death, similar to the pathological changes seen in many cases of human motor neuron diseases $^{11}$. The gene defect responsible for the motor neuron changes in pmn/pmn mice is still unknown. But an insufficient or defective expression of CNTF does not seem to be responsible for the degenerative changes. Northern blots of sciatic nerve reveal CNTF transcripts with similar size and intensity to those of the healthy controls. Western blots from sciatic and facial nerve extract are indistinguishable from those of controls and the same extracts contain comparable CNTF biological activity, as determined in the embryonic chick ciliary neuron survival assay (data not shown).

Because intravenously injected CNTF has a half-life of only a few minutes (F. Dittrich and M.S., unpublished results) and $\mathrm{pmn} / \mathrm{pmn}$ mice do not tolerate repetitive daily injections of CNTF, and because the available implantable infusion pumps are too large for 3-4 week-old mice, we established a stable cell line by transfection of mouse D3 cells $^{12}$ with a leader sequence/CNTF genomic DNA construct (Fig. 2a). CNTF is synthesized and released by these cells in high quantities. The effect of intraperitoneal injection of $5 \times 10^{7} \mathrm{CNTF}$-secreting D3 cells was compared with untreated controls from the same litters and with animals injected with untransfected D3 stem cells between post-natal day 20 and 21 (Fig. 1). Because homozygous pmn/pmn mice cannot be recognized before the onset of first paralytic symptoms, an earlier start of the treatment was precluded. Of four mice injected with untransfected D3 cells, three mice died between postnatal day 34 and 36 . In comparison, five out of eight untreated $\mathrm{pmn} / \mathrm{pmn}$ mice and seven out of eight

FIG. 1 A. Effect of CNTF on the survival of $p m n / p m n$ mice. Survival of eight untreated $p m n / p m n$ mice (dashed-line); eight $p m n / p m n$ mice injected at post-natal day 20 or 21 with $5 \times 10^{7}$ CNTF-secreting D3 cells (solid line); and four $\mathrm{pmn} / \mathrm{pmn}$ mice injected with $5 \times 10^{7}$ untransfected D 3 cells (dotted line) are shown. Triangles, time of cell injection; squares, time of death. $B$, $P m n / p m n$ mice of two independent experiments at 35 (1 and 2) and 40 (3 and 4) days old. a, c, CNTF-treated $p m n / p m n$ mice; $b$, $d$, untreated $p m n / p m n$ litter mates.
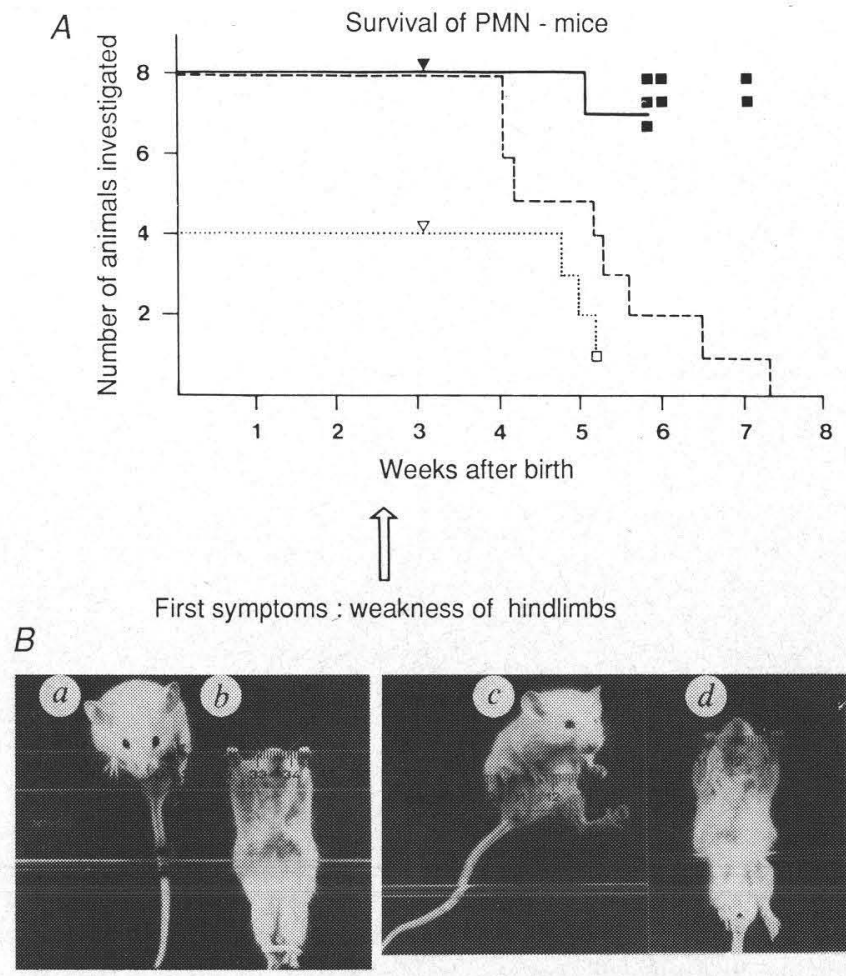


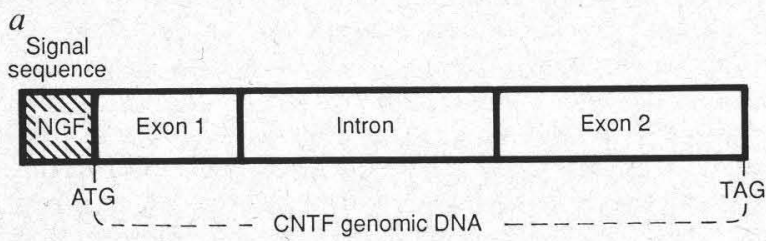

FIG. 2 a, Map of the construct used for stable transfection of mouse D3 stem cells: a fragment containing mouse CNTF genomic DNA, which includes the whole coding regions of exon I and II and a roughly 1,000-base pair (bp) intron, was cloned $3^{\prime}$ of a complementary DNA fragment coding for the first 20 amino acids of mouse prepro-nerve growth factor (starting from methionine -121 , which has been suggested as the translation initiation site for human and mouse $\mathrm{NGF}^{17}$ ), which includes the entire signal peptide sequence ${ }^{18}$. This construct was cloned into the $\mathrm{pRc} / \mathrm{CMV}$ expression vector (In VitroGen). After linearization with Pvul, $25 \mu \mathrm{g}$ plasmid DNA were used for transfection of $5 \times 10^{6}$ mouse D3 embryonic stem cells by electroporation. Clones were selected by G 418 treatment $^{12}$ for neomycin resistance and analysed for CNTF expression. In contrast to cells transfected with native CNTF, which do not release $\mathrm{CNTF}^{19,20}$, more than $70 \%$ of the total ciliary neuronal survival activity was released from these cells into the culture medium after $40 \mathrm{~h}$ in culture. b, Morphology of the intraperitoneal tumours that had formed 3 weeks after intraperitoneal injection of $5 \times 10^{7}$ D3 cells in a pmn/pmn mouse at postnatal day 21. Paraffin sections were prepared and stained with haematoxylin-eosin. Scale bar, $100 \mu \mathrm{m}$. c, CNTF biological activity in: I, Sera from pmn/pmn mice after intraperitoneal injection of transfected CNTF-secreting D3 cells. The survival of isolated chick embryonic day- 8 ciliary neurons was determined ${ }^{13}$ after addition of sera from $p m n / p m n$ mice at dilutions from $1: 1,000$ to $1: 100$. One trophic unit is defined here as the volume of serum per $\mathrm{ml}$ of medium that supports half-maximal survival of the cultured neurons. II, A neutralizing antiserum against rat $\mathrm{CNTF}^{21}$ (prepared by repeated immunization of a rabbit with rat CNTF) was used as a control for the specificity of the bioassay for CNTF. This antiserum $\left(5 \mu / \mathrm{ml}^{-1}\right.$ medium), which completely abolished the survival effect of $1 \mathrm{ng}$ CNTF in cultures of ciliary neurons, inhibited the survival activity observed with the sera shown in I. III, Sera from four untreated $p m n / p m n$ mice and from one $p m n / p m n$ mouse treated with untransfected D3 cells were also tested and were inactive at the same concentrations (dilution 1:1,000 to $1: 100$ in the culture medium).
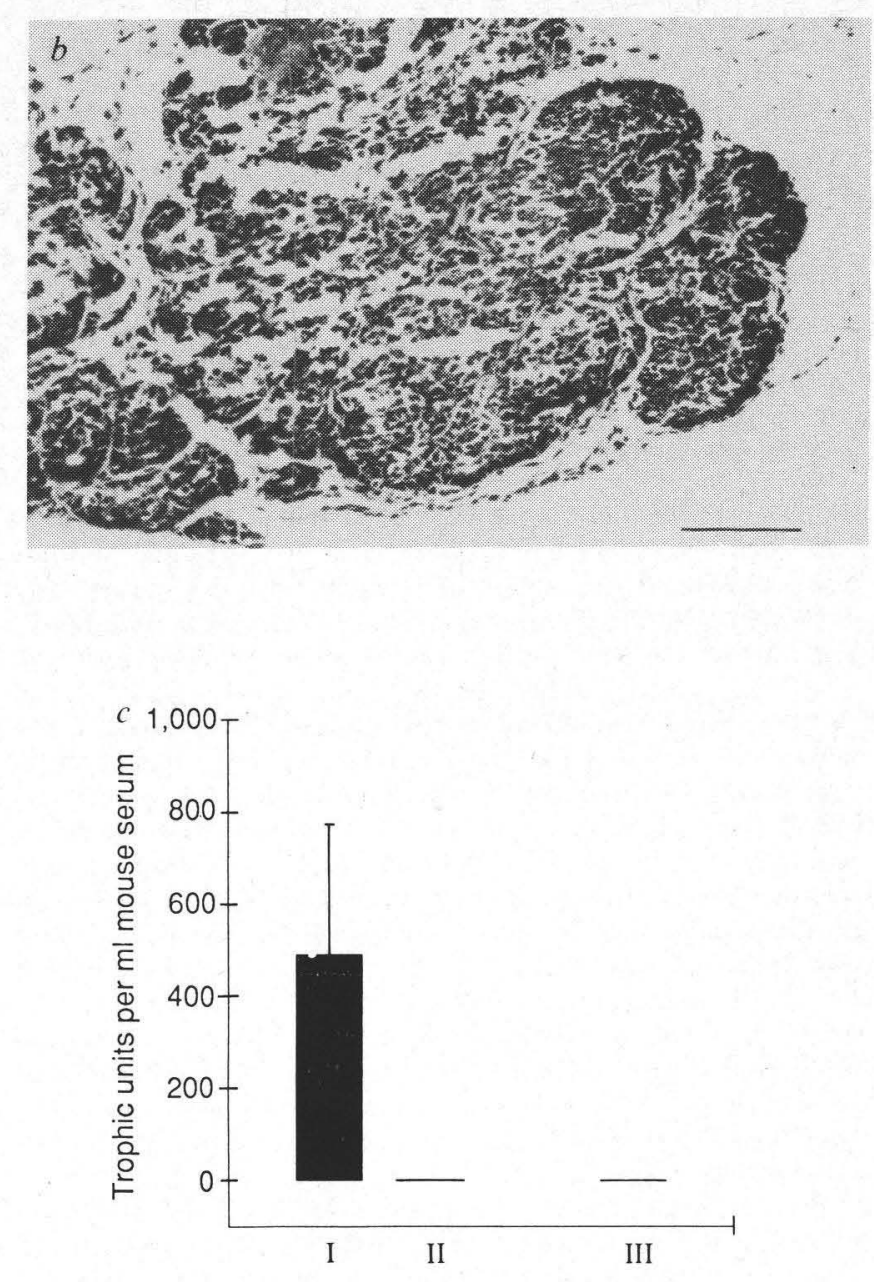
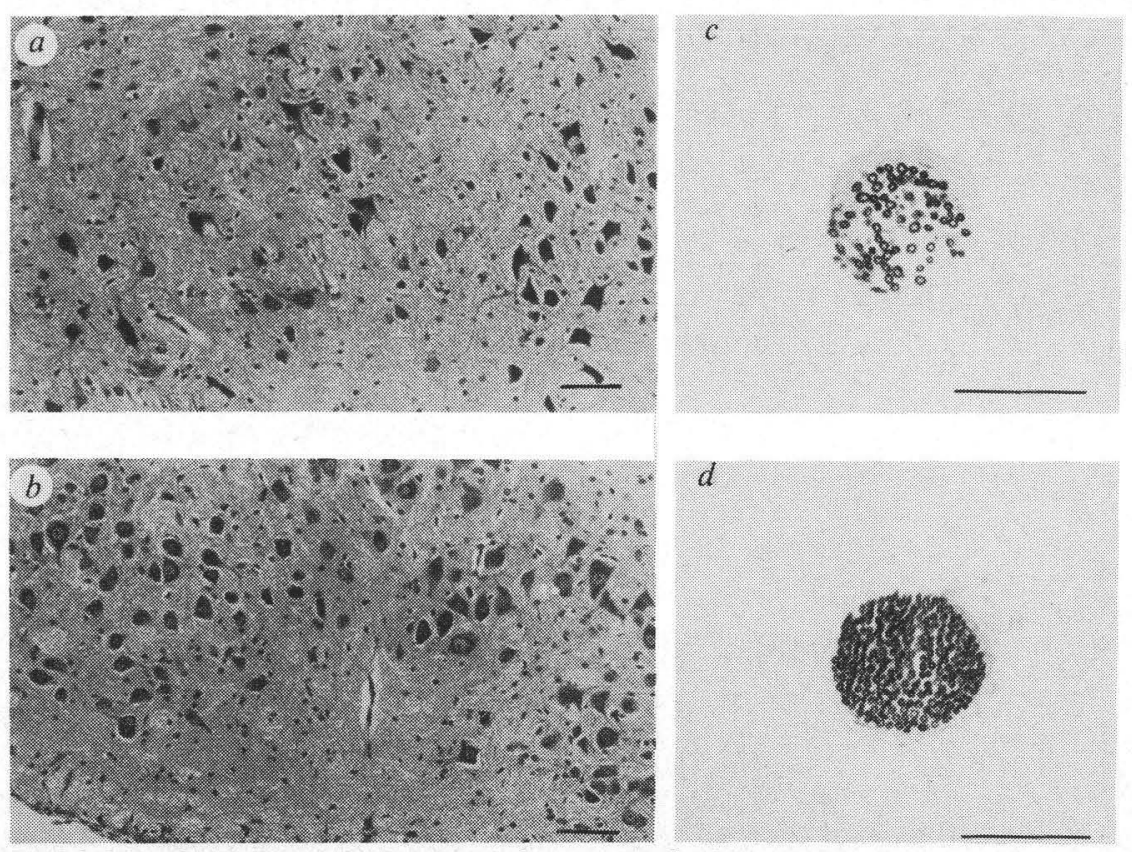

FIG. 3 Morphology of the facial nucleus $(a, b)$ and phrenic nerve $(c, d)$ of untreated $p m n / p m n$ mice $(a, c)$ and $p m n / p m n$ mice injected with CNTFsecreting D3 cells $(b, d) . a, b$, The motor neurons are more numerous, larger and vary less in diameter in the CNTF-treated mouse $(b)$ than in the untreated mouse $(a)$. Chromatolysis tends to be less pronounced after CNTF-treatment. $c, d$, Distal phrenic nerves of an untreated $p m n / p m n$ mouse at day 43 and of a CNTF-treated $p m n / p m n$ mouse at day 48 . The nerve of the CNTF-treated animal (d) appears to be much better preserved and contains more myelinated axons than that of the untreated animal (c). Scale bars, $100 \mu \mathrm{m}(a, b)$, or $50 \mu \mathrm{m}(c, d)$. 
CNTF-treated $p m n / p m n$ mice were still alive at postnatal day 36 . The fact that the intraperitoneal injection of untransfected D3 stem cells and the intraperitoneal growth of teratoma-like tissue (Fig. $2 b$ ) even increased the death rate in $p m n / p m n$ mice is a further demonstration that these animals are very sensitive to any kind of surgical intervention.

of eight CNTF-treated mice analysed, seven were still alive at postnatal day 40 when $50 \%$ of untreated $\mathrm{pmn} / \mathrm{pmn}$ mice had already died (Fig. 1A). Moreover, these mice were capable of a better motor performance than the untreated $\mathrm{pmn} / \mathrm{pmn}$ mice. In contrast to the latter, they could still climb onto a ruler when allowed to grip it with their forepaws (Fig. $1 B$ ).

CNTF-treated and non-treated mice were killed between postnatal day 40 and 48. After establishing deep ether anaesthesia, blood was taken by cardial puncture and the mice were perfused with $4 \%$ formaldehyde. Brain stem, phrenic nerve and tumour tissue formed in the peritoneal cavity of D3 cell-treated animals were prepared for morphological analysis. Sera were tested for CNTF activity (Fig. 2c) (13,14 $^{1}$ and significant levels of ciliary neuronal survival activity $\left(492 \pm 282\right.$ trophic units $\mathrm{ml}^{-1}$ serum $)$ were detected in the treated animals. Sera from untreated $p m n / p m n$ mice did not show noticeable survival activity.

To determine motor neuron cell numbers we chose the facial nucleus because of the absence of interneurons in this well delineated structure. Interneurons present in the ventral horn of the spinal cord could erroneously be counted as atrophic

\section{Received 21 April; accepted 22 June 1992}

1. Arakawa, Y., Sendtner, M. \& Thoenen, H. J. Neurosci. 10, 3507-3515 (1990).

2. Magal, E., Burnham, P. \& Varon, S. Devl Brain Res, 63, 141-150 (1991).

3. Oppenheim, R. W., Prevette, D., Qin-Wei, Y., Collins, F. \& MacDonald, J. Science 251, 1616-1618 (1991).

4. Sendtner, M., Kreutzberg, G. W. \& Thoenen, H. Nature 345, 440-441 (1990).

5. Schmalbruch, H., Jensen, H. J. S., Bjaerg, M., Kamieniecka, Z. \& Kurland, L. J. Neuropath. exp. Neurol. 50, 192-204 (1991).

6. Duchen, L. W. \& Strich, S. J. J. Neurol. Neurosurg. Psychiat. 31, 535-542 (1968).

7. Kaupmann, K., Simon-Chazottes, D., Guenet, J. L. \& Jockusch, H. Genomics 13, 39-43 (1992)

8. Pollin, M. M., McHanwell, S. \& Slater, C. R. J. Neurocyt. 19, 29-38 (1990)

9. Messer, A. \& Flatherty, L. J. Neurogenet. 3, 345-355 (1986).

10. Messer, A. Strominger. N. L. \& Mazurkiewicz, J. E. J. Neurogenet. 4, 201-213 (1987)

11. Hirano, A. \& Iwata, M. in Amyotrophic Lateral Sclerosis (eds Tsubaki, T. \& Toyokura, Y.) 107-134 (University Park Press, Baitimore, 1979). motor neurons. In comparison to untreated controls, the number of motor neurons in the facial nucleus was greatly decreased in $p m n / p m n$ mice and the treatment with CNTF exhibited a large protective effect (Table 1; and Fig. $3 a, b$ ). CNTF supports the survival of single motor neurons in cell culture ${ }^{14}$, suggesting that the protective and restorative effects of CNTF in $\mathrm{pmn} / \mathrm{pmn}$ mice are mediated directly on motor neurons rather than by skeletal muscle. Moreover, the number of axons in the phrenic nerve was significantly increased by CNTF treatment, that is $87 \pm 4$ axons in untreated and $144 \pm 22$ in CNTF-treated pmn/pmn mice (Table 1; and Fig. $3 c, d$ ).

The data presented indicate that CNTF efficiently rescues motor neurons from degeneration in $\mathrm{pmn} / \mathrm{pmn}$ mice. Moreover, the large loss of axons in the phrenic nerve, presumably representing the cause of death in $\mathrm{pmn} / \mathrm{pmn}$ mice, can be significantly reduced by CNTF treatment. Because initial symptoms cannot be recognized in $p m n / p m n$ mice before the third postnatal week, it is to be expected that at this time the disease has already reached a relatively advanced stage, so that treatment can only begin when the degeneration of motor neurons has already started. The number of phrenic nerve fibres is already reduced to $30 \%$ in 28 -day-old $\mathrm{pmn} / \mathrm{pmn}$ mice ${ }^{5}$. The beneficial effects of CNTF in advanced stages of motor neuron degeneration in $\mathrm{pmn} / \mathrm{pmn}$ mice indicates that treatment of human degenerative motor neuron diseases may eventually be possible.

12. Gossler, A., Doetschman, T., Korn, R., Serfling, E. \& Kemler, R. Proc. natn. Acad. Sci. U.S.A. 83, 9065-9069 (1986)

13. Hughes, S. M., Lillien, L. E., Raff, M. C., Rohrer, H. \& Sendtner, M. Nature 335, 70-73 (1988).

14. Sendtner, M., Arakawa, Y., Stöckli, K. A., Kreutzberg, G. W. \& Thoenen, H. J. Cell Sci. 15 (suppl.), 103-109 (1991).

15. Oppenheim, R. W. J. comp. Neurol. 246, 281-286 (1986)

16. Klüver, H. \& Barrera, E. J. Neuropath. exp. Neurol. 12, 400-403 (1953).

17. Ullrich, A., Gray, A., Berman, C. \& Dull, T. J. Nature 303, 821-825 (1983).

18. Scott, J. et al. Nature 302, 538-540 (1983).

19. Lin, L.F. H. et al. Science $246,1023-1025$ (1989)

20. Stöckli, K. A. et al. Nature 342, 920-923 (1989).

21. Sendtner, M. Stöckli, K. A. \& Thoenen, H. Lell Biol (in the press).

ACKNOWLEDGEMENTS. We thank W. Komp, H. Thorun and A. Kussmaul for technical assistance, and $L$. Bale for linguistic revision of the manuscript. This work was supported by a grant to M. S. from the Hermann und Lilly Schilling Stiftung im Stifterverband für die Deutsche Wissenschaft. 